\title{
Field, Mega- and Microscopic Description of the Volcaniclastic Red Beds and the Associated Scoriaceous Basalt of Wadi Al Roaian, Ablah Area, Assir Terrain
}

\author{
Abdullah R. Sonbul \\ Engineering and Environmental Geology Department, Faculty of Earth Sciences, King Abdulaziz University, \\ Jeddah, KSA \\ Email:dr.asonbul@yahoo.com
}

Received 8 June 2016; accepted 25 July 2016; published 28 July 2016

Copyright (C) 2016 by author and Scientific Research Publishing Inc. This work is licensed under the Creative Commons Attribution International License (CC BY). http://creativecommons.org/licenses/by/4.0/

(c) (i) Open Access

\begin{abstract}
The study area is located in the entrance of Wadi Girshah in Ablah area, Assir terrain, southwestern Saudi Arabia. The present study aims to shed light on the field, mega- and microscopic description of the volcaniclastic red beds and the associated scoriaceous basalts of Wadi Al Roaian. It is based mainly up on the field works augmented by petrographic description. The present study revealed that, the succession of the upper part of Girshah Formation comprises three main horizons: 1) lower unit of epidotized and silicified basaltic and andesitic tuffs; 2) middle unit of volcaniclastic red beds-scoriaceous basalts of successive cycles (each of these cycles begins by reddish tuffaceous mudstone and sandstone and is terminated by the calcite-bearing scoriaceous basalt). This unit indicated the deposition in lacustrine environments and the red iron oxyhydroxides minerals were formed either by the direct hematitization of the deposited tuffs or by the diagenetic hematitization of the green clays formed instead of the precursor tuffaceous materials; 3 ) upper scoriaceous basalt unit composed from hematitized and calcitized basalt. The unit was formed by basic volcanic eruptions in subaerial condition which was predominated by the formation of calcium carbonate lakes associated with the progressive and subsequent calcitization of the Ca-plagioclase minerals of the basalt and the associated glassy tuffaceous material. The scoriaceous basalts of Wadi Al Roaian area represent subaerial basic volcanic eruption in continental situation and are associated with subsequent events of mineral alteration and formation of secondary minerals i.e. calcite, hematite and goethite.
\end{abstract}

\section{Keywords}

Scoriaceous Basalts, Arabian Shield Rocks, W. Al Roaian, Ablah Area, Volcaniclastic Red Beds 


\section{Introduction}

\subsection{General Geology and Physiography}

Ablah area lies in the extreme southeast corner of Saudi Arabia. It is about $280 \mathrm{~km}$ southeast of At Ta'if. The area is bounded by latitudes $20^{\circ} 00^{\prime} \mathrm{N}$ and $20^{\circ} 28^{\prime} \mathrm{N}$, and longitudes $41^{\circ} 46^{\prime} \mathrm{E}$ and $41^{\circ} 58^{\prime} \mathrm{E}$. The succession of Ablah Group was studied and subdivided by [1]. He subdivided the rock units in Ablah district into the following rock units which are arranged from base to top into: Girshah Andesite, Khutnah Formation, Jerub Formation and Ablah Formation. The Ablah Formation itself was subdivided by [1] into the followings: lower green unit, upper green unit, lower red unit, siltstone-dolostone unit, and upper red unit which are further subdivided into lower, middle and upper member. [2] described the succession of Ablah Formation under the term Ablah group (Cryogenian-Ediacarian layered rocks), and he concluded that the group is restricted to the volcanic and sedimentary rocks in the vicinity of the Ablah prospect (Figure 1). Recently, the Neoproterozoic volcano-sedimentary

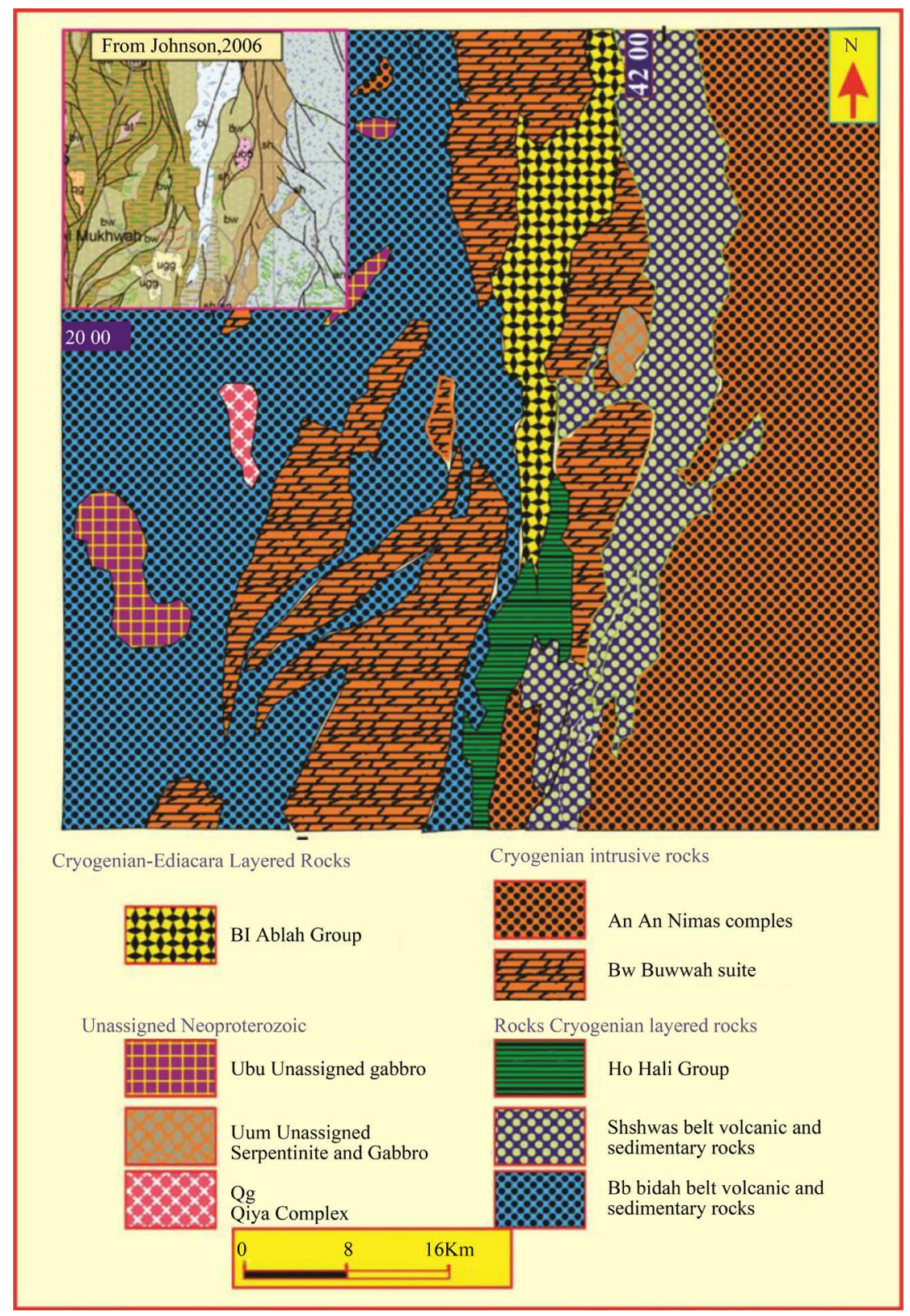

Figure 1. Geologic map of Ablah area [2]. 
succession of Wadi Girshah area has been assigned by [3] consisting of three main units and they concluded that this succession was formed during intermittent periods of volcanism, tectonism, and sedimentation within inter-arc, back-arc, and intra-arc depositional settings. Recently, [4] described the origin and geochemistry of the volcaniclastic green and red beds of Tayibit El Esm area. They formulated the stages of formation of red beds and pointed out that, the red beds were formed by the diagenetic hematitization of the green celadonitic clays as well as the direct hematitization of unceladonitized tuffaceous materials of the middle and upper parts of the depositional cycles and the formation of goethite, hematite, and iron-oxyhydroxides.

The present field observations on Ablah area revealed that, the area comprises five main rock units; these are from the older to the younger (Figure 2): 1) Girshah Formation which is present in the western part of Ablah

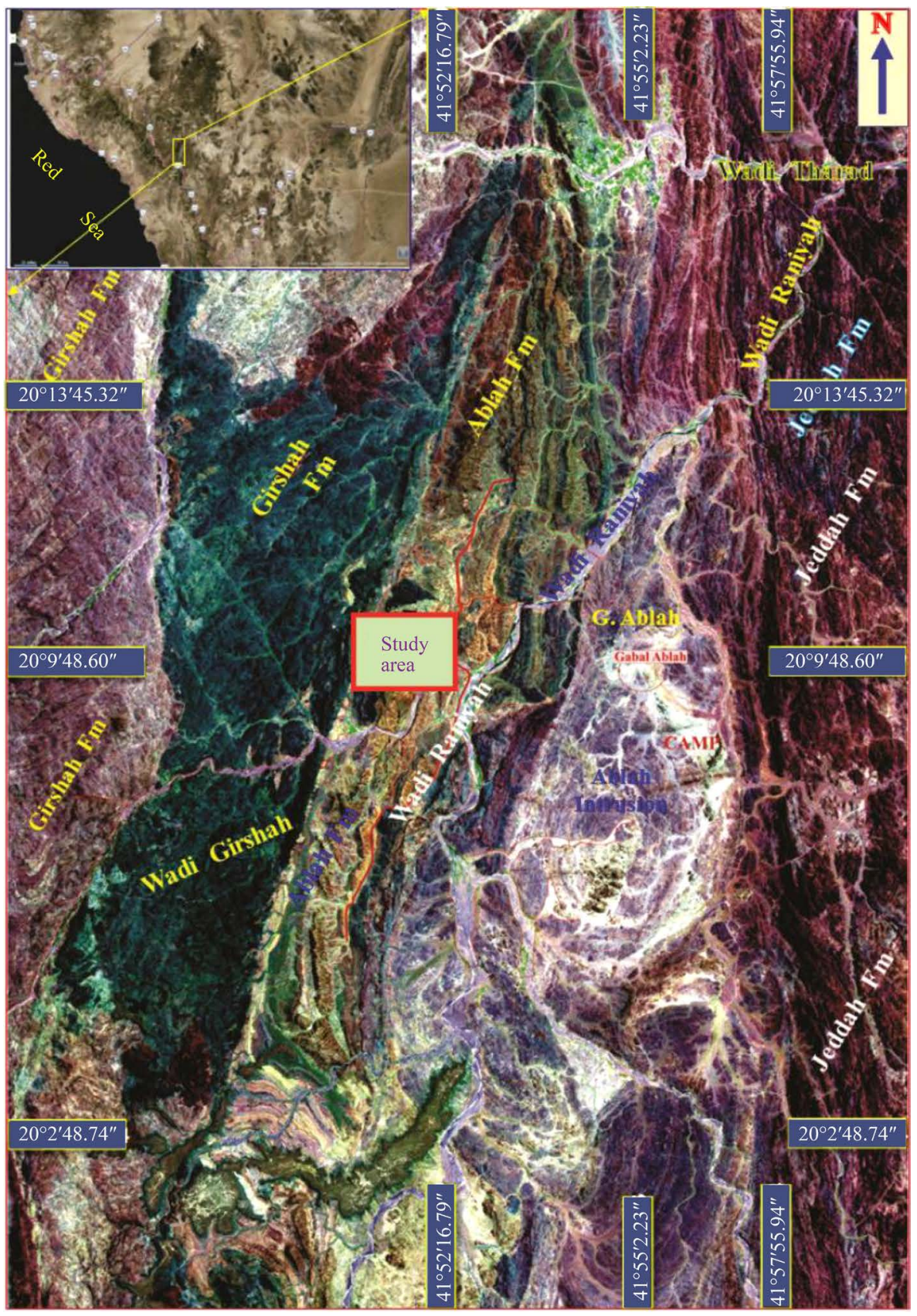

Figure 2. Regional satellite image of Ablah area showing the main rock units and geomorphologic features. 
area and it is composed mainly from basaltic and andesitic tuffs and agglomerates, 2) Ablah Formation which is composed from thick volcano-sedimentary succession of interbedded rhyolites, acidic agglomerates and conglomerates, red and green mudstones, sandstones and yellow dolostones, 3) Ablah intrusion which is present in the central part of the study area and it is composed mainly from diorite, quartz diorite, granite and quartz, 4) Jeddah formation which is present in the eastern part of the study area (Figure 2). It is composed from chlorite schist, amphibolies and slates of greenstone belt facies, and 5) the quaternary deposits which are mainly located in the main wadies, i.e. Wadi Raniyah, Wadi Girshah, Wadi Tharad and Wadi Kohlah (Figure 2).

\subsection{Aims of the Study}

The present study aims to shed light on the field, mega and microscopic description of the volcaniclastic red beds and the interbedded scoriaceous basalts of the upper parts of Girshah Formation in Wadi Al Roaian area, Ablah district. This will help in the clarification of the geologic events that predominated in the volcano-sedimentary basin during the transition in the depositional environments during the formation of Girshah and Ablah formations.

\subsection{Materials and Methods}

The study is based up on the detailed field works and measurements using the satellite images of Ablah area. Detailed stratigraphic section was measured for the different units of the volcaniclastic red beds and the associated scoriaceous basalt. The collected samples are used for thin section preparation. The different horizons of the studied succession are petrographically described.

\subsection{Geology of Wadi Al Roaian Area}

Generally, the rock units northwest and south east of Wadi Al Roaian area are arranged from the older to the younger as follows (Figure 3):

Unit I: which is present in the western part of the study area. It is composed mainly from basic and intermediate volcanics and the intercalated volcaniclastic green and red beds. The studied volcaniclastic red beds and the scoriaceous basalts are present within this unit;

Unit II: which is present just overlying unit I. It is composed mainly from acidic unit of rhyolite, rhyolitic tuffs and chertified dolostones.

Unit III: which is present in the extreme eastern part of the study area. It is composed mainly from thick volcano-sedimentary conglomerates, agglomerates within carbonate and rhyolite interbeds.

The area as a whole is composed from north-south trending units of basic and acidic volcaniclastics and the volcanic equivalents (basalts and rhyolites). Some basic dikes cross-cut this succession and trend in east-west direction are observed. Along both sides of wadi Al Roaian, the upper part of the black sequence of Girshah Formation with its contact with the overlying lighter acidic succession of Ablah Formation is present (Figure 4(a)). Thinly laminated unit of yellow dolostones and tuffaceous mudstone is present along the contact between the two formations (Figure 4(b)). The Girshah Formation is of black color and consists mainly from interbedded volcaniclastic green and red beds with thin volcaniclastic conglomerate and agglomerate interbeds (Figure 4(c) and Figure 4(d)). The sequence is terminated by characteristic volcaniclastic red beds with diagnostic scoriaceous basalt unit "the aim of the present work". This horizon is overlain directly with thinly bedded highly silicified chertified dolostones (marble) (Figure 4(e)). This unit is followed upward by interbedded green mudstones, yellow dolostone and terminated by reddish brown to black rhyolite horizon in cyclic nature (Figure 4(e) and Figure 4(f)). This succession was formed by successive periods of acidic volcanism and volcaniclastic sedimentation.

\subsubsection{Silicified-Chertified Carbonates}

The lower silicified stromatolitic carbonates "marble unit" is of very diagnostic banding and lamination nature. It is composed mainly from successive soft carbonate beds in its lower parts and terminated by hard silicified stromatolitic horizon (Figure 5(a)). The upper hard part is thinly laminated and composed from light grey and dark laminae (Figure 5(a)). Some brown chert nodules are observed cross cut the lamination nature (Figure $5(b))$. 


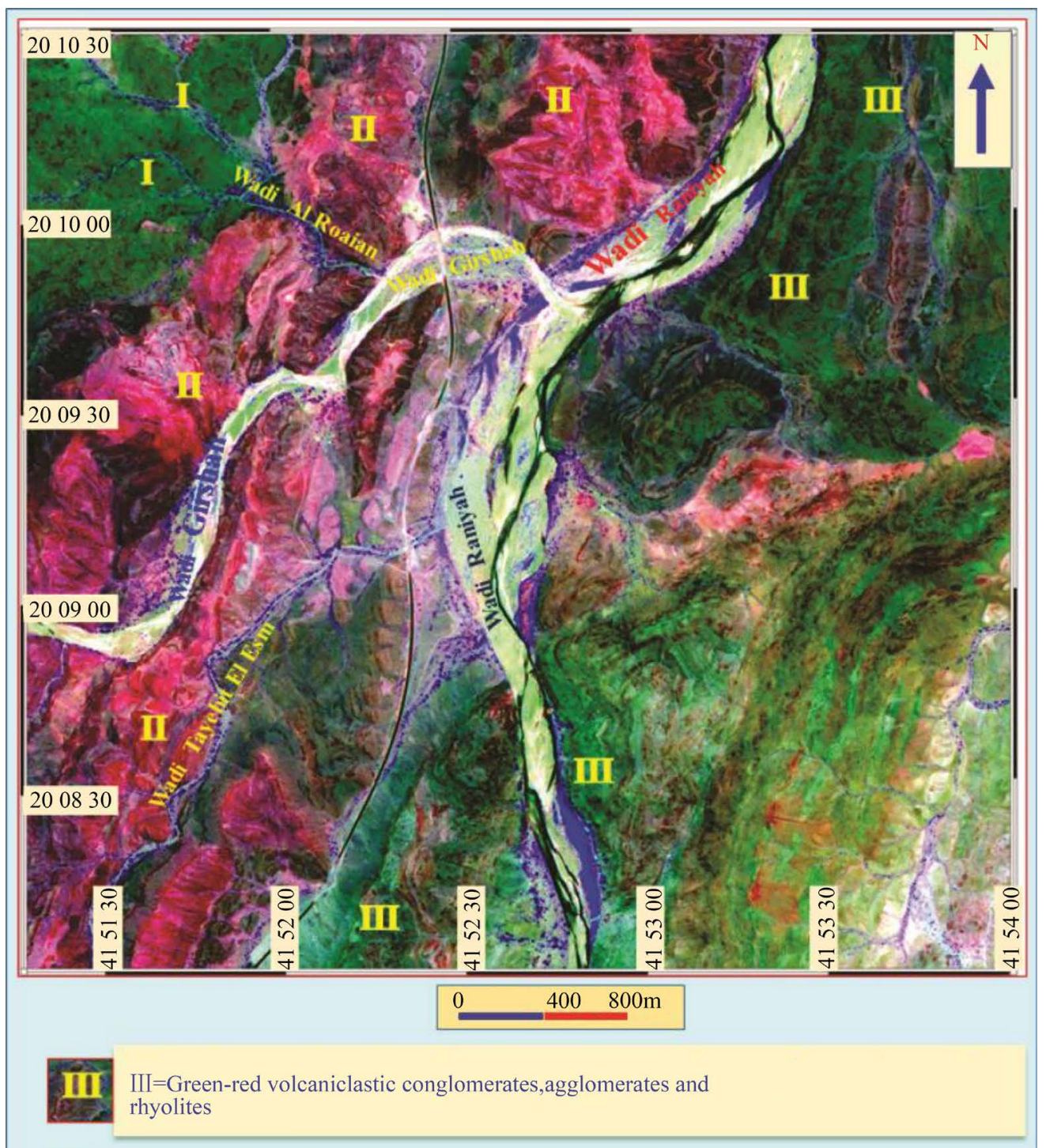

II.

II =Acidic unit of rhyolite, rhyolitic tuffs and chertified dolostones

I = Basic volanics and related volcaniclastic of Girshah Fm(the studied volcaniclastics and Scoriaceous basalts)

Figure 3. Close up (detailed) satellite image of Wadi Girshah-Wadi Al Roaian area showing the different rock units from the west (older) to the younger (east).

The microscopic description of this marble horizon led to the recognition of two main petrographic types: 1) thinly laminated stromatolitic chertified marble which is composed from thinly laminated micrit and microcrystalline quartz (Figure 6(a) and Figure 6(b)). Some black undevitrified laminae and flasers are still seen within this petrographic lithotyope, 2) the non-laminated type of marble is composed from interlocked microcrystalline euhedral calcite and quartz aggregates (Figure 6(b) and Figure 6(c)). There is a strong evidence supporting the formation of this type of marble during the progressive and subsequent stages of diagenetic devitrification of precursor tuffaceous materials. This process lead to the formation of microcrystalline calcite which is latter on replaced by microcrystalline quartz (Figure 6(c) and Figure 6(d)). 

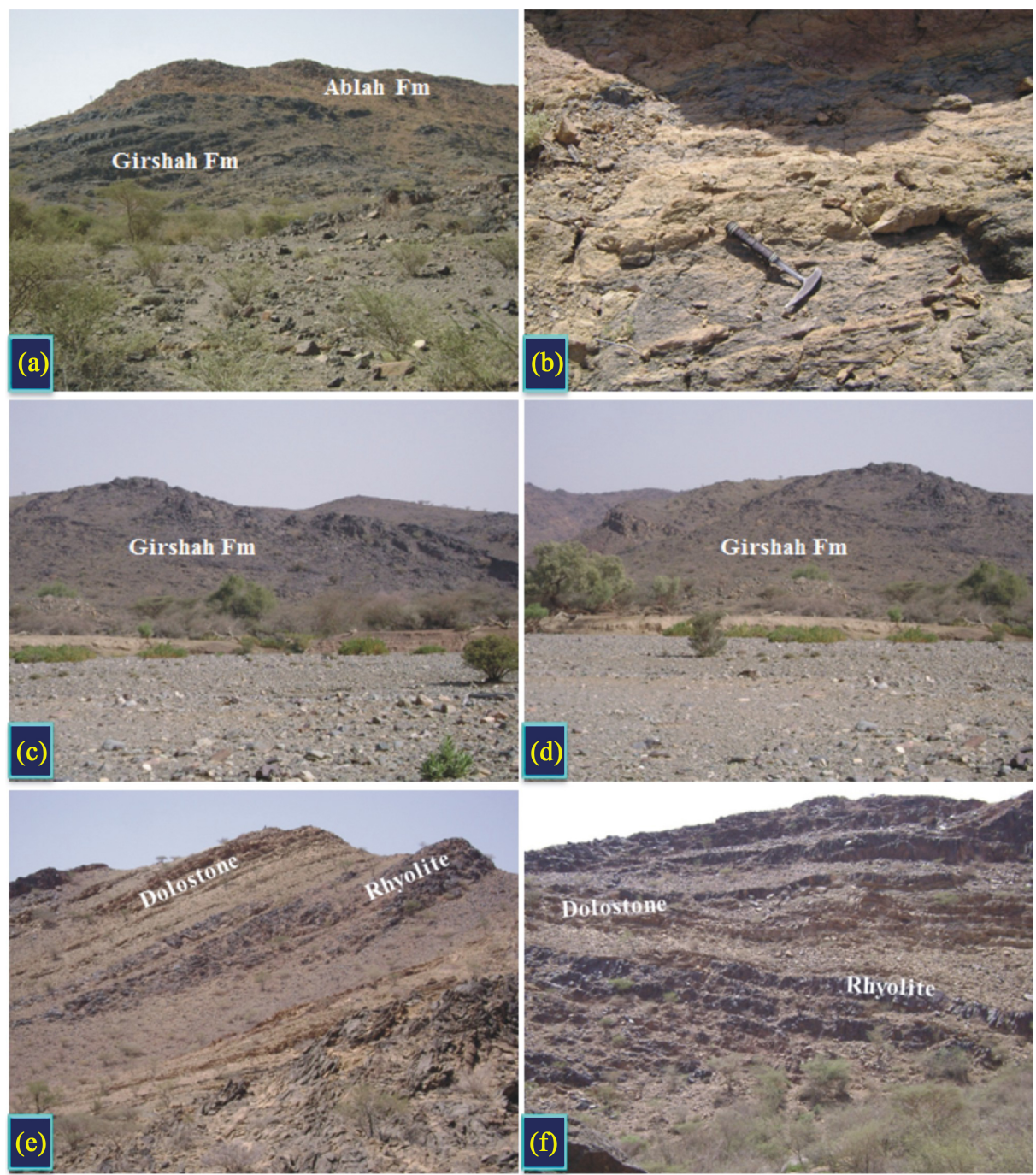

Figure 4. (a) The Ablah Formation "light” overlying the Girshah Formation “dark”, W. Al Roaian; (b) Close up view showing the contact between Girshah Formation and Ablah Formation; (c) (d) Details of the basalts, andesites and volcaniclastics of Girshah Formation; (e) (f) Details of the interbedded yellow dolostones "light”, mudstones and rhyolites “dark" of Ablah Formation.

\subsubsection{Rhyolites}

The succession of wadi Al Roaian comprises several rhyolitic beds intercalated with the green clays and the yellow dolostones. The microscopic description of the rhyolite indicates that, they are of coarse crystal sizes and composed mainly from coarse K-feldspar crystals, quartz and hematitized biotite flakes (Figure 6(e) and Figure 6(f)). Some of the K-feldspar crystals show signs of alteration and kaolinization and formation of clay minerals (Figure 6(e)). Most of the rhyolite horizons are actually bedded where thin rhyolitic tuffs and/or green clays and dolomite are present intercalated with the rhyolite beds [3].

\section{The Volcaniclastic Red Beds and the Associated Scoriaceous Basalts}

The detailed field, mega-, and microscopic description of the studied volcaniclastic red beds and the associated scoriaceous basalts led to the recognition of three main units (Figure 7). These units are clearly identified in the field and the boundaries between these units are transitional. The lower unit is similar to the interbedded volcanics and the intercalated volcaniclastics but it consists mainly from volcaniclastic deposited in distal situations far away from the volcanic vent (proximal source). The volcaniclastic red beds unit is of characteristic red color 

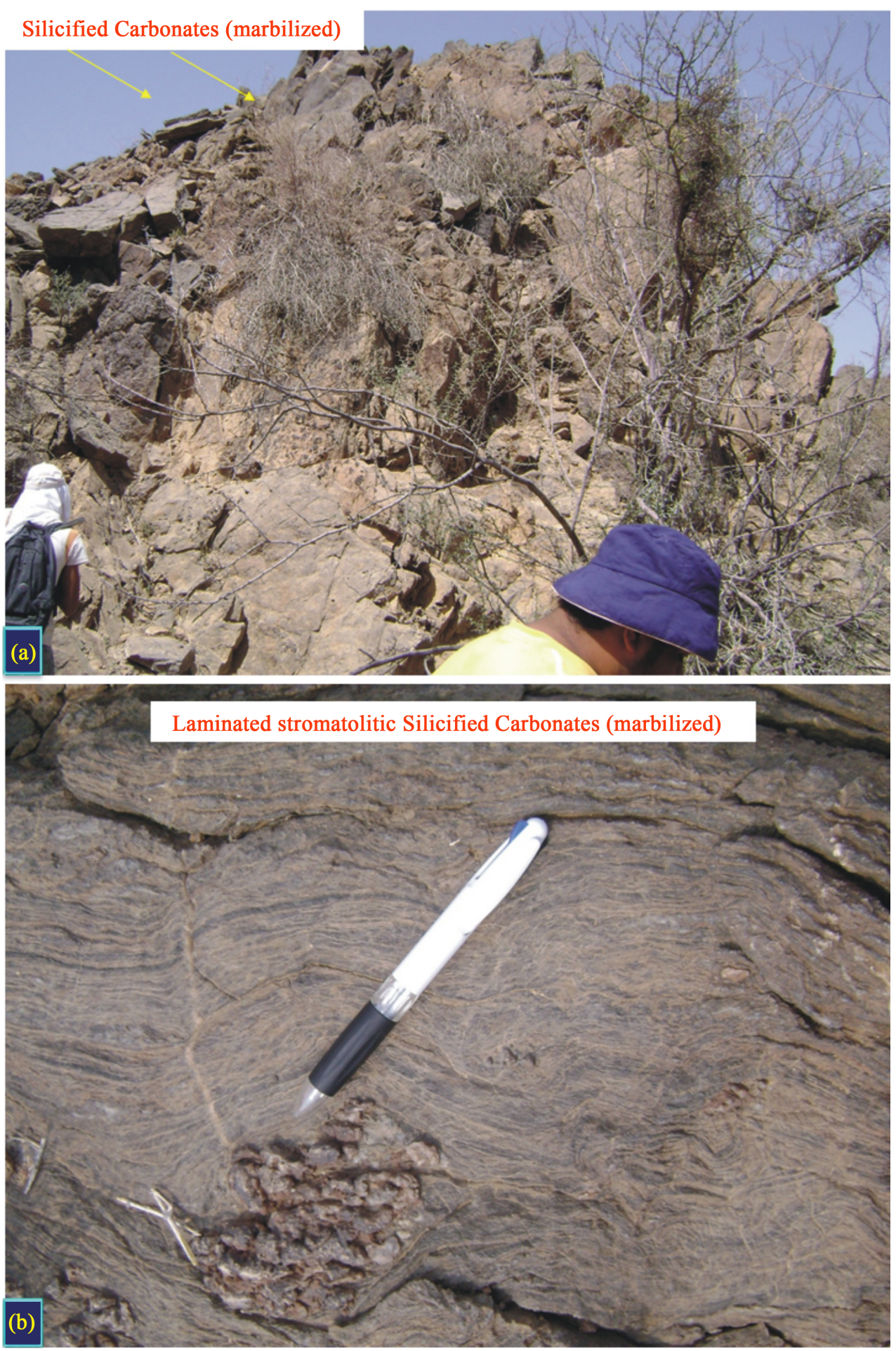

Figure 5. (a) Bedded silicified-chertified "marbilized" stromatolitic carbonates of the lower part of Ablah Formation in W. Al Roaian area; (b) Close-up view of the laminated stromatolitic silicified carbonates of Figure 5(a).

and bedding. The scoriaceous basalt unit is ill bedded and of mottled nature (black and white domains). These units are from the base to the top as follows: Unit I: Lower epidotitized and silicified andesitic basaltic tuff, Unit II: Middle volcaniclastic red beds-scoriaceous basalt, and Unit III: Scoriaceous basalt. 

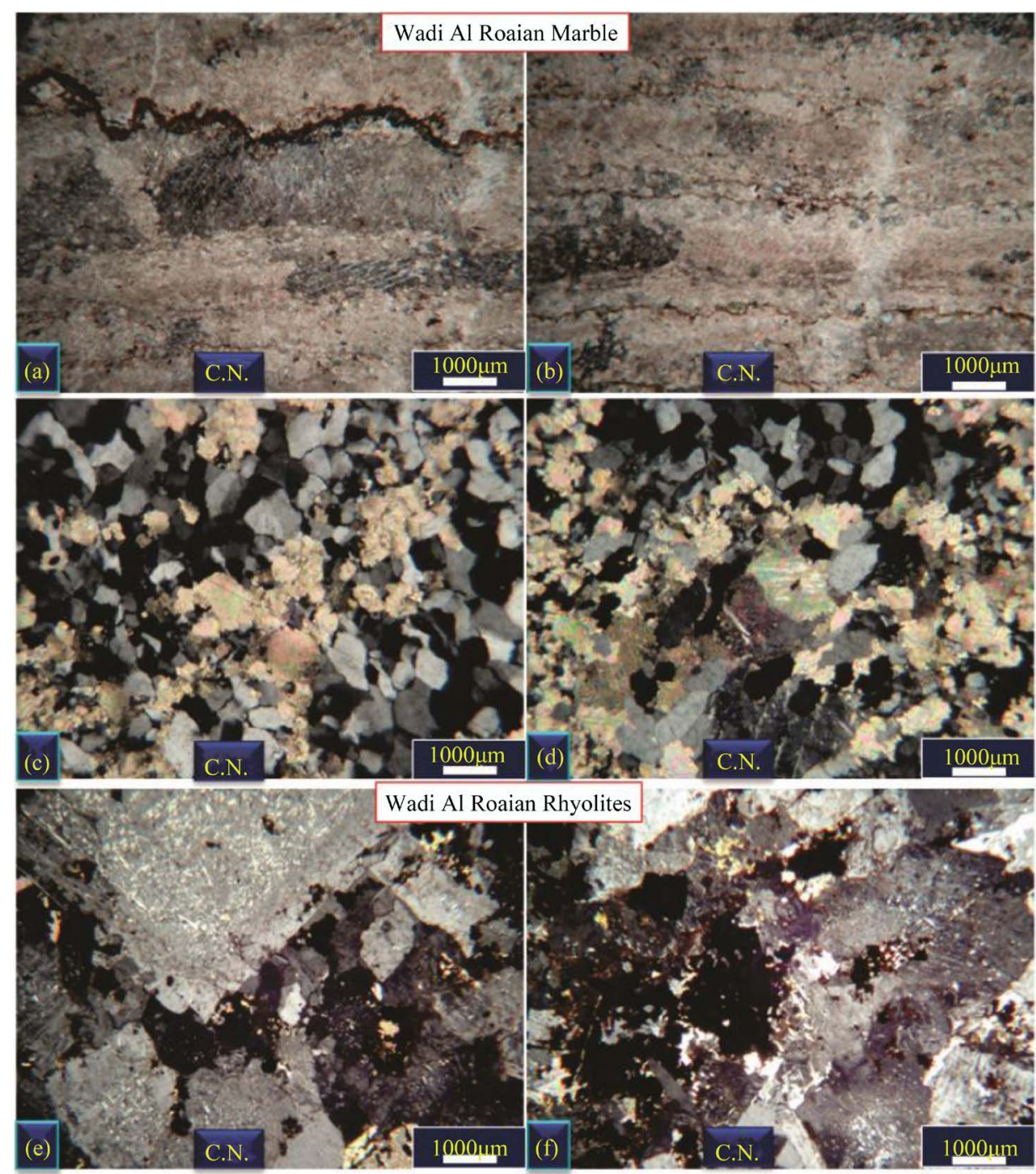

Figure 6. (a) (b) Laminated stromatolitic carbonates composed mainly from microcrystalline calcite and quartz; (c) (d) Coarse crystalline quartz and calcite in the stromatolitic carbonates of the lower parts of Ablah Formation; (e) (f) The K-feldspars, quartz, and biotite of coarse crystalline rhyolite of Ablah Formation, W. Al Roaian. O. L. = Ordinary Light; C. N = Crossed Nicols.

\subsection{Unit I: Lower Epidotitized and Silicified Andesitic Basaltic Tuff}

This unit forms the left hand ledge after $600 \mathrm{~m}$ from the entrance of wadi Al Roaian from wadi Girshah. It attains up to $6 \mathrm{~m}$ thick and it is of bedded nature and composed from alternating light green bands and dark bands (Figure 8(a) and Figure 8(b)). There is a gradational changes from the dark bands to the light green ones. This unit is highly fractured giving rise to some separated blocks (Figure 8(c)). The detailed microscopic description of this unit revealed it composition from aggregates of epidote of small to medium crystal sizes and of green second order interference color (Figure 8(d)). It contains some sporadically distributed light grey quartz and pinkish calcite crystals (Figure 8(d)). The green epidote was suffered from two types of diagenetic alteration, the first one is the calcitization and the second one is the silicification.

\subsubsection{Calcitization}

This process begins by the formation of small calcite veinlets and small patches (Figure 8(e)). Within these veinlets, light grey to white quartz aggregates are seen. Also, green epidote crystal aggregates are still seen 


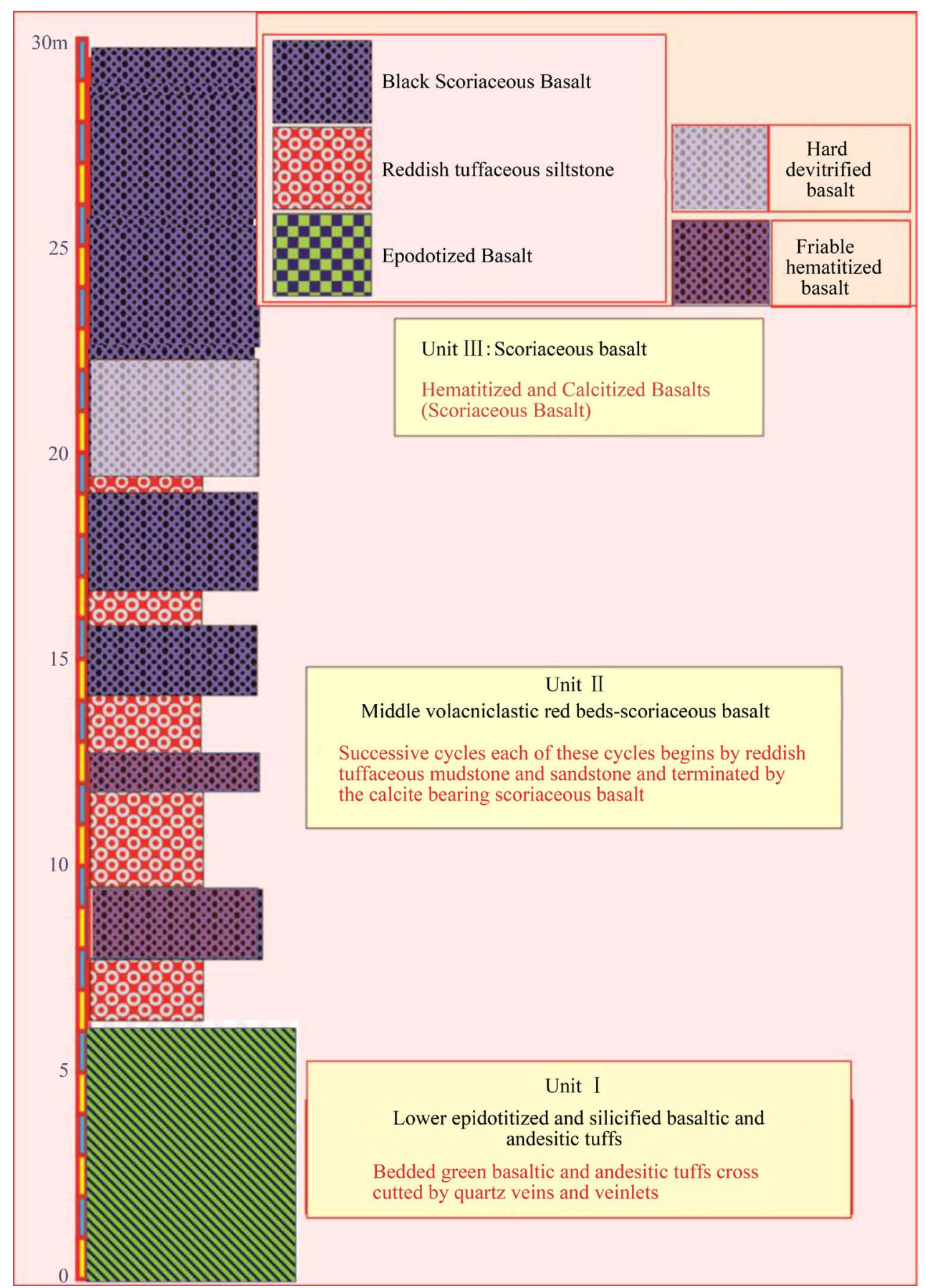

Figure 7. The detailed stratigraphic section of the studied volcaniclastic red beds and the associated scoriaceous basalts of W. Al Roaian area.

within the formed calcite veinlets (Figure 8(e)). During the progressive and subsequent stages of calcitization, the formed calcite small aggregates become coalesced together forming large blocky calcite crystals of characteristic rhombohedral cleavage (Figure 8(f)). This process is also accompanied with the formation of large euhedral prismatic epidote crystals (Figure $8(\mathrm{f})$ ). The progress of calcitization processes is accompanied with the corrosion of the epidote by the calcite leaving very small relicts of colored epidote crystals within the formed blocky calcite (Figure 9(a)). Ultimate stages of calcitization led to the formation of large areas of blocky calcite contains very small relicts of highly corroded and embayed epidote crystals (Figure 9(b)). 


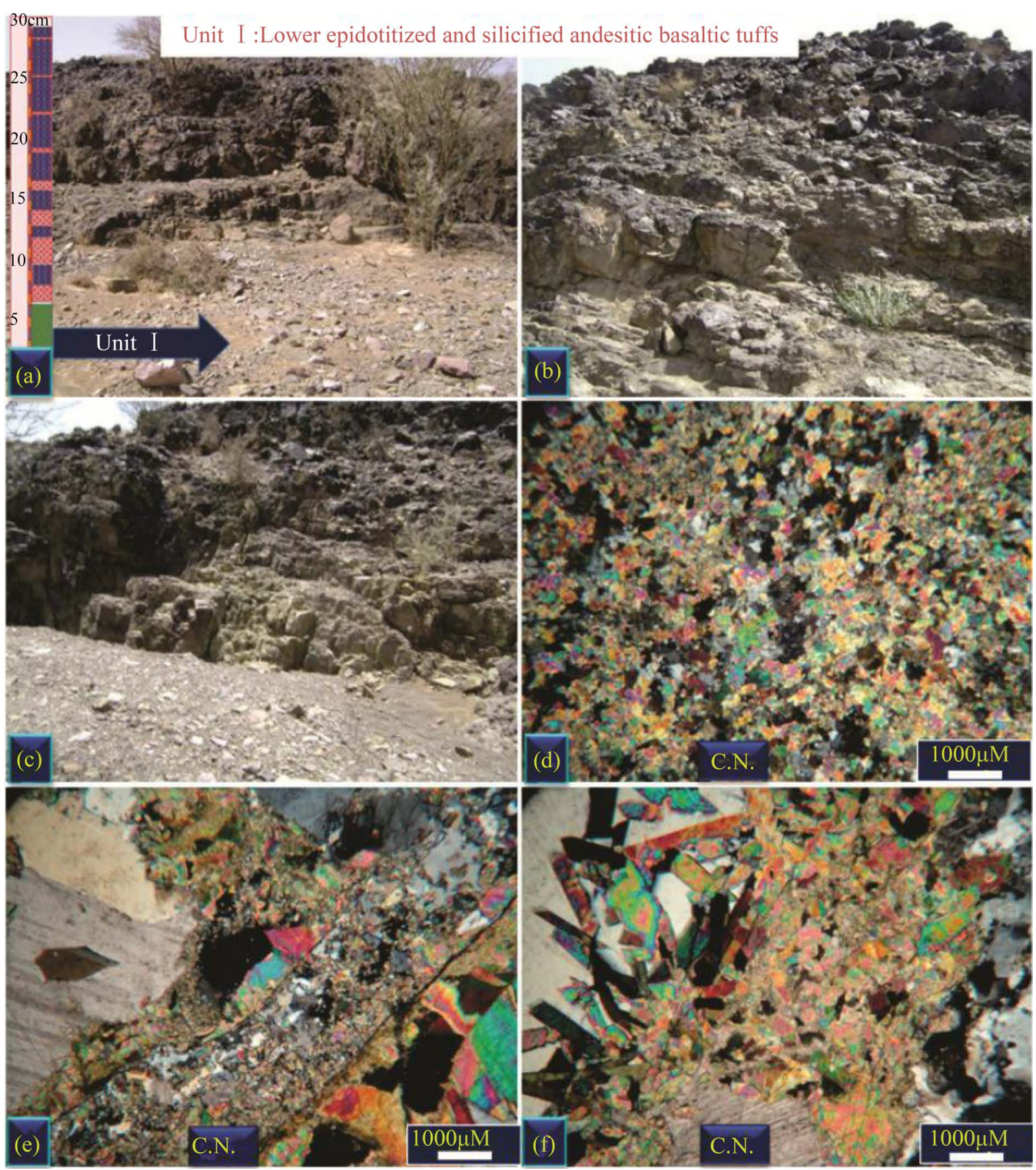

Figure 8. (a)-(c) The lower epitotitized and silicified andesitic basaltic tuff, notice the bedding nature and the fracture system; (d) Aggregates of epidote of small to medium crystal sizes and of green second order interference color; (e) Small calcite veinlets and small patches within the epidote aggregates; (f) The formed calcite small aggregates of (e) become coalesced together forming large blocky calcite crystals of characteristic rhombohedral cleavage.

\subsubsection{Silicification}

This process is predominated within the formed large calcite domains where light grey quartz aggregates were seen formed instead of the calcite (Figure 9(b)). The progress of this process led to the formation of large quartz domains (Figure 9(c)). These domains of quartz are still contains small calcite and epidote aggregates (Figure 9(c)). Ultimate stages of silicification led to the formation of large quartz crystals with very small relicts of euhedral crystals (Figure 9(d)). 

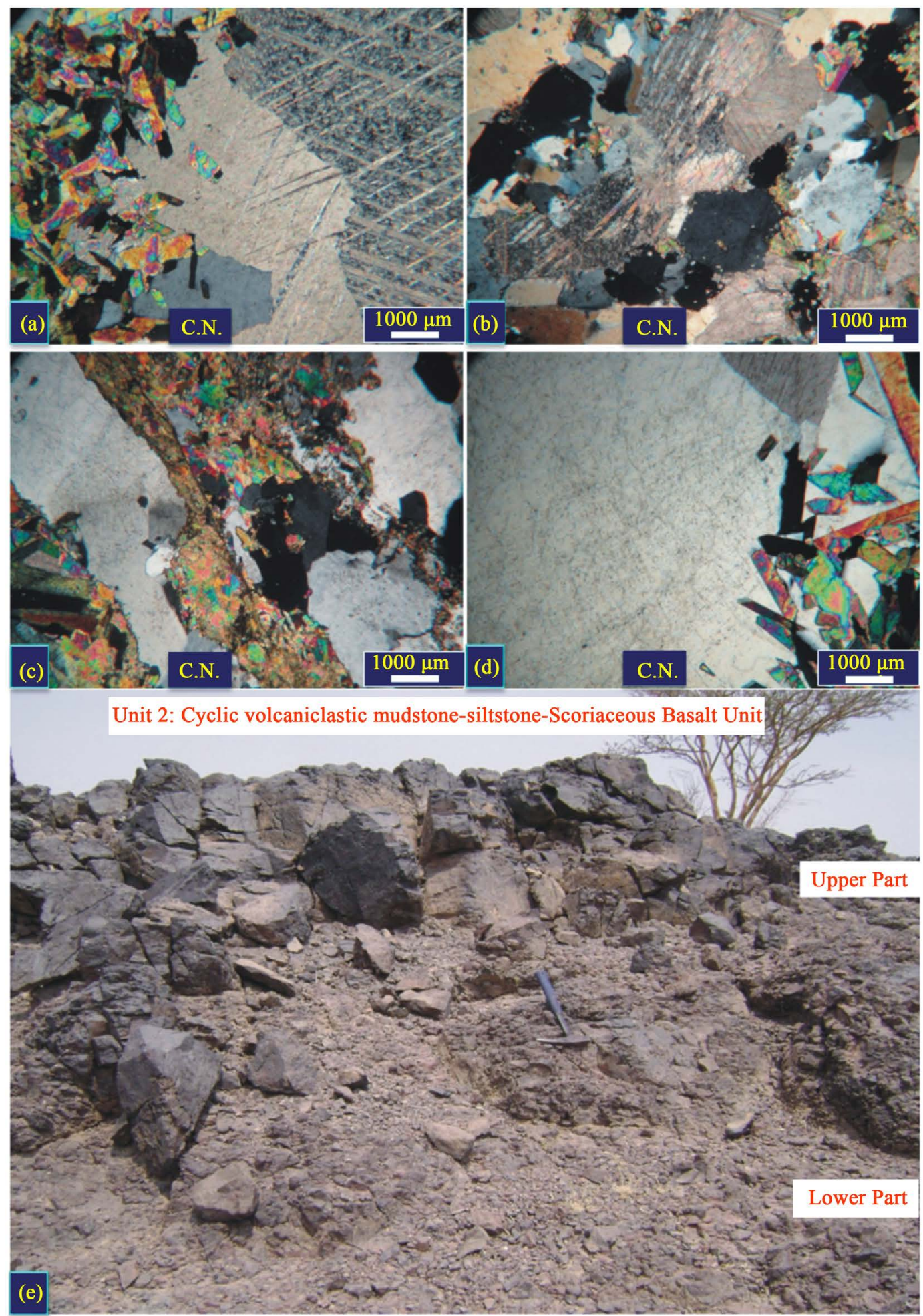

Figure 9. (a) Corrosion of the epidote by the calcite leaving leaving very small relicts of colored epidote crystals within the formed blocky calcite; (b) Ultimate stages of calcitization and the formation of large areas of blocky calcite contains very small relicts of highly corroded and embayed epidote crystals; (c) The progress of the silicification process and the formation of large quartz domains (grey); (d) Ultimate stage of silicification and the formation of large quartz crystals "grey" with very small relicts of euhedral crystals of epidote "colored"; (e) Field photo of the second unit II of the measured section. 


\subsection{Unit II: Cyclic Volcaniclastic Red Beds-Scoriaceous Basalt}

This unit is present just overlying unit I. It forms a characteristic slope unit and attains up to $16 \mathrm{~m}$ thick (Figure 7). It is composed from successive cycles, each of these cycles begins by reddish tuffaceous mudstone and sandstone and terminated by calcite-bearing scoriaceous basalt (Figure 9(e), Figure 10(a)). The cycles of the lower
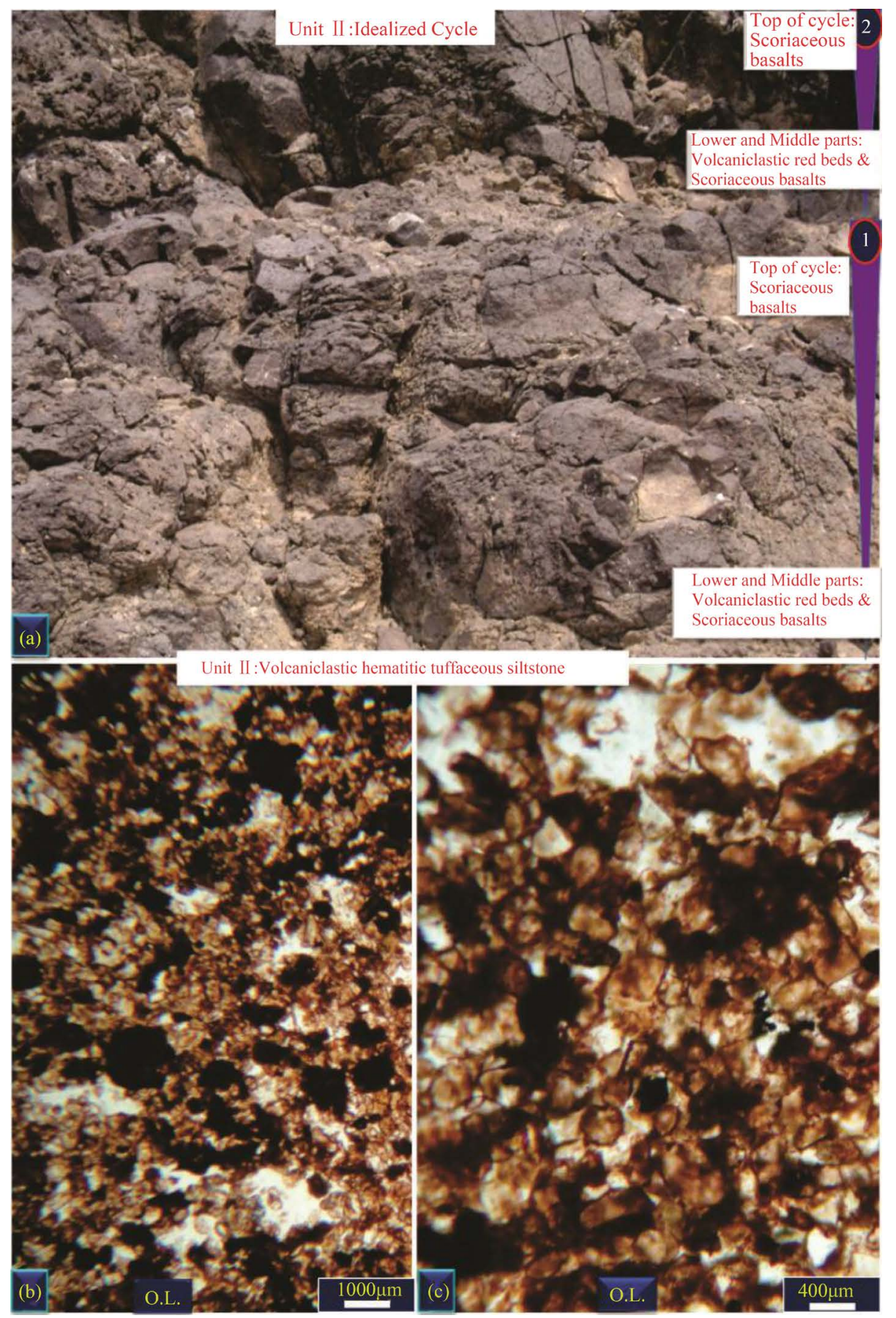

Figure 10. (a) Close-up view of the small cycles of the volcaniclastic red beds-scoriaceous basalt unit II, the base of the cycles are composed from hematitic tuffaceous mudstone-siltstone while their tops are composed from the scoriaceous basalt; (b) (c) The hematitic volcaniclastic tuffaceous mudstone-siltstone of the lower parts of the cycles, notice the goethite and hematite cement formed instead of the precursor tuffaceous materials. 
parts of the succession are of thick basal red tuffaceous mudstone-siltstone while those of the upper parts are of thin red tuffaceous mudstone-siltstones and thick scoriaceous basalt (Figure 7, Figure 10(a)).

The detailed microscopic description of the different cycles of this unit revealed the composition of these cycles from two main horizons:

\subsubsection{The Hematitic Volcaniclastic Tuffaceous Mudstone-Siltstone}

These are predominated in the lower parts of the cycles and are composed from precursor tuffaceous materials that suffered from two main diagenetic processes, these are: 1) Devitrification processes that led to the formation of microcrystalline quartz aggregates instead of the amorphous tuffaceous materials (Figure 10(b)). The formed quartz aggregates are of irregular boundaries and of low relief which support its formation by diagenetic devitrification and are not of detrital allogenic origin (extra-basinal), and 2) Hematitization processes which is predominated during oxic-diagenetic processes. During the initial stages, the deposited precursor tuffaceous materials become slightly oxidized giving rise to honey color light chocolate brown materials instead of the precursor tuffaceous materials or instead of the microcrystalline quartz aggregates formed during the devitrification stages (Figure 10(c)). The progress of the hematitization processes led to the formation of blood red to reddish brown phase, i.e. iron-oxyhydroxides or goethite (Figure 10(c)). Ul timate stages of diagenetic dehydration and recrystallization of this amorphous phase led to the formation of black crystalline high relief phase, i.e. hematite (Figure 10(c)). It is observed that, the microcrystalline quartz phase is subsequently subjected to progressive hematitization, corrosion and embayment by the formed iron minerals phases (Figure 10(c)).

\subsubsection{Scoriaceous Basalt}

Which terminates the volcaniclastic hematitic mudstone-siltstone of the lower and middle parts of the cycles (Figure 11(a) and Figure 11(b)). This type of basalt terminates the small scale cycles and it is present in two main types:

1) Hematitized Friable Scoriaceous Basalt

Which terminates the small cycles of the lower part of this unit II. It is of reddish color and very friable (Figure 11(a) and Figure 11(b)). Microscopically, this type of basalt is composed mainly from highly hematitized olivine and pyroxenes giving-rise to black hematite patches and crystallites (Figure 11(a) and Figure 11(b)). The black hematite show evidences supporting its formation at final stages of diagenetic hematitization of precursor olivines and pyroxenes. These evidences include: 1 ) the presence of very small relicts of yellowish green parental olivine and pyroxene minerals (Figure 11(c)), 2) the presence of blood red amorphous iron oxyhydroxides patches and domains associated with the black hematite (Figure 11(d)), and 3) the presence of blood red amorphous iron-oxyhydroxides domains partially replaced by the black hematite minerals and usually coated and replaced by the black hematite which indicate the formation of hematite instead of these blood red amorphous iron oxyhydroxides (Figure 11(d)).

The white groundmass of this type of basalt is composed from a mixture of clay minerals (idingesite and sericite) formed instead of 1) the original Ca-plagioclase lathes and the associated palagonite groundmass, 2) calcite formed by the calcitization of the Ca-plagioclase and the tuffaceous glassy matrix. Some green vesicles are observed within this groundmass (Figure 11(e) and Figure 11(f)). These are mostly formed as a result of chloritization or greening of precursor clay minerals. The honey texture of these domains and its grey interference color support its chloritic composition. These vesicles show a pronounced zonation from the core to the outer rim.

2) Calcitized Basalts

In which the cycles of the upper parts of this unit II, are terminated by calcitized basalts (Figure 12(a) and Figure 12(b)). This type of basalt is hard, massive and contains some white color calcite patches and domains (Figure 12(b)). Microscopically, this type of basalt is composed mainly from lath-like prismatic Ca-feldspar crystals with less frequent hematitized olivine and pyroxene crystals (Figure 12(c) and Figure 12(d)). This basalt type shows incipient stages of calcitization of the Ca-plagioclase and formation of blocky calcite (Figures 12(c)-(f)). These stages begin with the central, then rim and finally irregular calcitization of the Ca-plagioclase crystals (Figures 12(c)-(f)). Ultimate stages of calcitization led to the formation of large areas of blocky calcite of characteristic rhombohedral cleavage. Small relicts of the prismatic Ca-plagioclase crystals are still seen within the formed calcite domains (Figure 12(e) and Figure 12(f)). The iron oxides that resulted from the oxidation of olivines and pyroxenes are also intensively calcitized. 

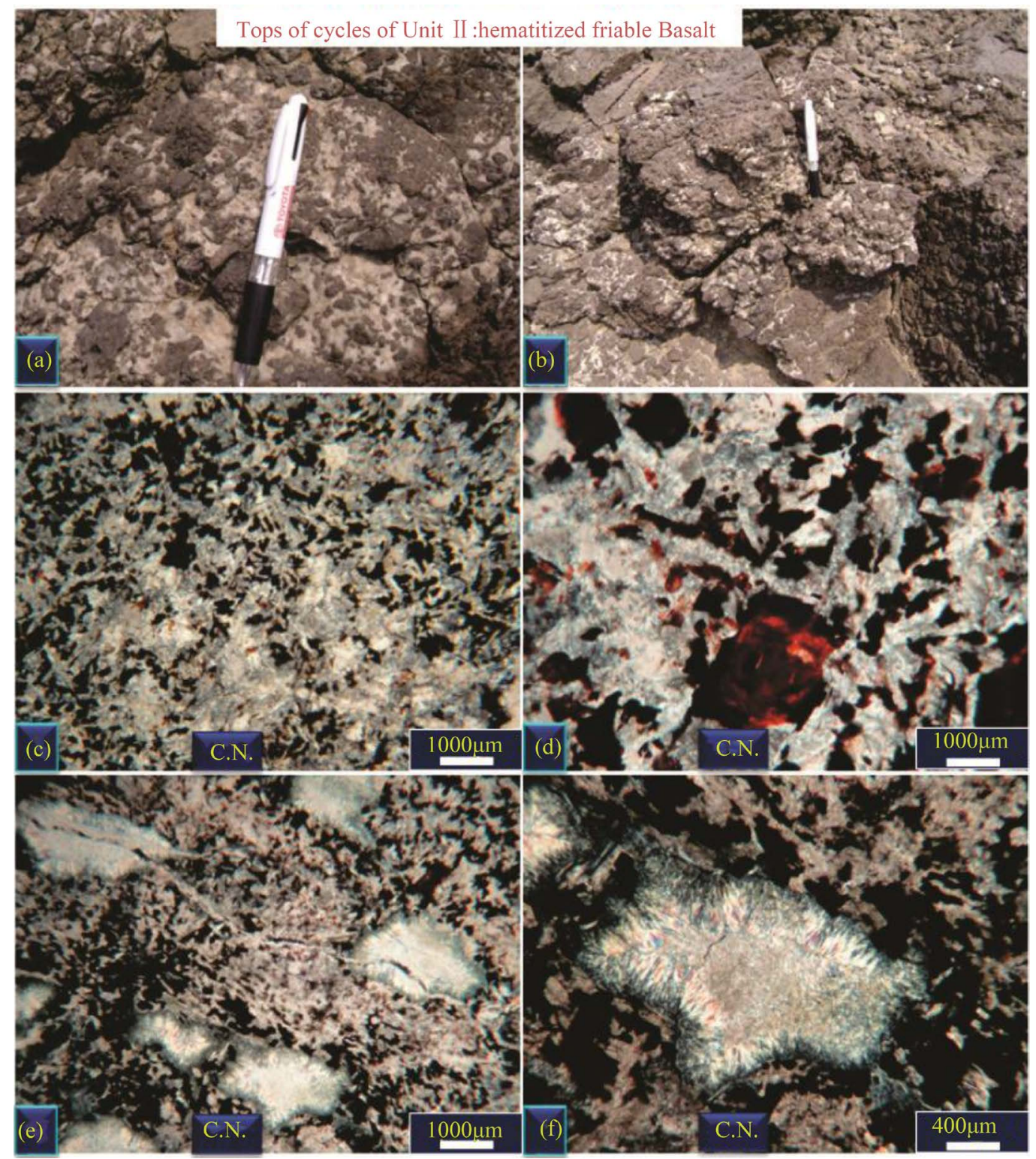

Figure 11. (a) (b) Hematitized friable scoriaceous basalt which terminates the small cycles of the lower part of this unit II; (c) Very small relicts of yellowish green parental olivine and pyroxene minerals within the calcite "light"-rich scoriaceous basalt; (d) Amorphous iron-oxyhydroxides "blood red" patches and domains associated with hematite "black" formed by the alteration of the original mafic "olivines and pyroxenes" of the basalts; (e) (f) Clay minerals "light grey" and calcite "white" formed by the calcitization of the Ca-plagioclase and the tuffaceous glassy matrix.

\subsection{Calcitized Hard Basalt}

This unit shows vertical variation in crystal size and it attains up to $15 \mathrm{~m}$ thick and comprises two main horizons: Lower devitrified basalt and upper hard calcitized basalt.

\subsubsection{Devitrified Basalt}

This type of basalt is fine-grained and it is present in the lower part of this unit. It attains up to $3.5 \mathrm{~m}$ thick and it is of light color. Microscopically, this type of basalt is very fine crystalline "glassy" and it is composed from Ca-plagioclase crystallites embedded within very fine glassy matrix (Figure 13(a) and Figure 13(b)). Towards the middle and upper parts of this horizon, the glassy matrix becomes slightly crystalline giving rise to lighter 

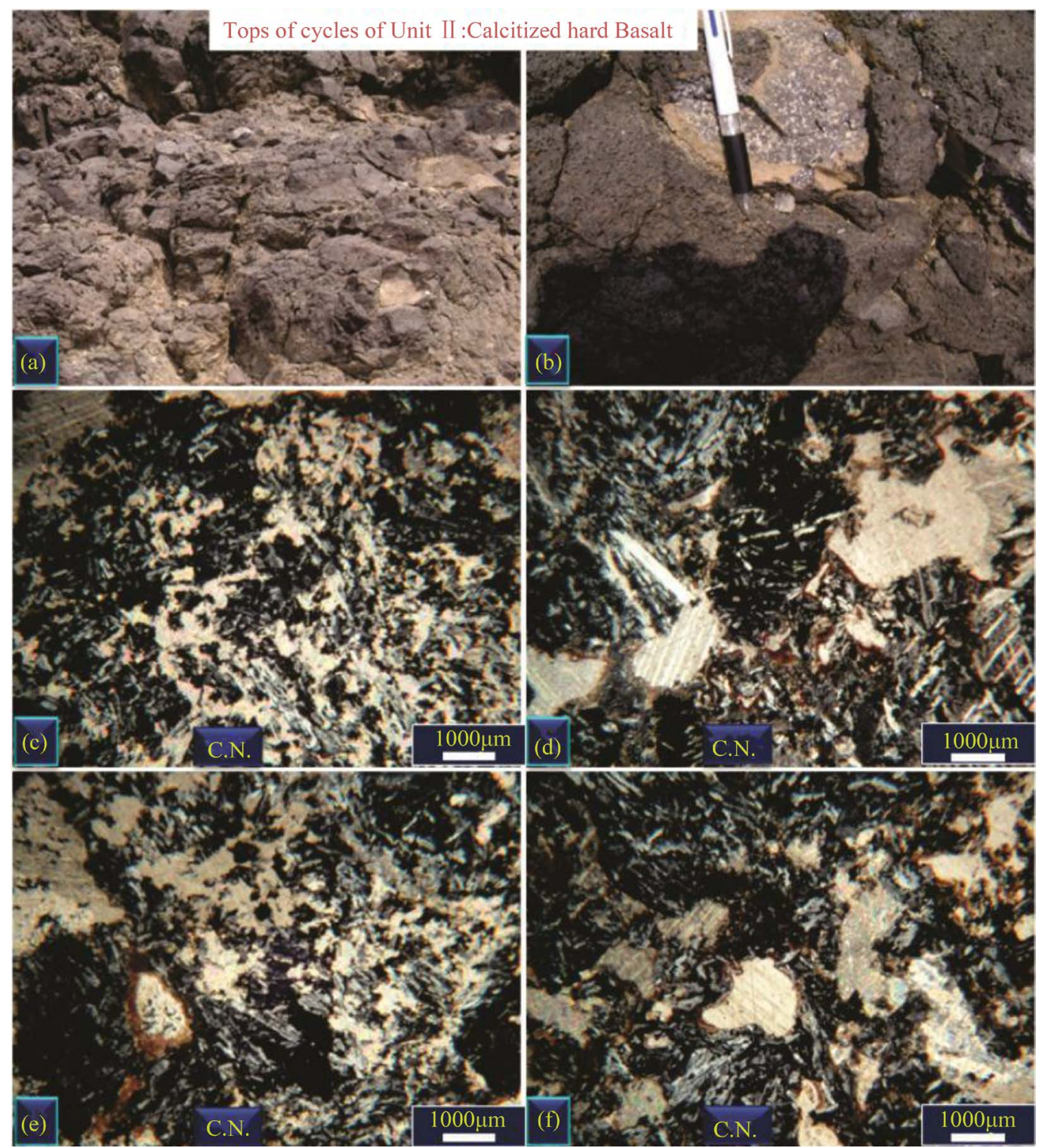

Figure 12. (a) (b) Calcitized basalts in the upper parts of the cycles of unit II, notice the white calcite patches and domains; (c) (d) Scoriaceous basalt composed mainly from lath-like prismatic Ca-feldspar crystals "grey" with less frequent hematitized olivine and pyroxene crystals "black" with minor calcite "very light" crystals; (e) (f) Ultimate stages of calcitization and the formation of large areas of blocky calcite of characteristic rhombohedral cleavage.

groundmass of Ca-plagioclase crystallites and microcrystalline quartz (Figure 13(c) and Figure 13(d)). In the upper part of this horizon, the basalt becomes holocrystalline (Figure 13(e) and Figure 13(f)).

It is observed that, all the components of this basalt are slightly calcitized and large blocky calcite crystals are seen formed instead of the basaltic components (Figure 13(e) and Figure 13(f)).

\subsubsection{Upper Hard Calcitized Basalt}

This unit attains up to $15 \mathrm{~m}$ thick and it is present in the topmost part of the succession (Figure 7) and it represents the final stages of the subaerial volcanic eruption. It is poorly bedded and it is composed from mottled "in situ pseudo-brecciated" basalt (Figure 14(a) and Figure 14(b)). The pseudo-brecciation nature of this type of basalt is related to the white calcitized ones (Figure 14(a) and Figure 14(b)). It is observed that, the degree of calcitization is increased from the lower to the middle and then the upper parts. 

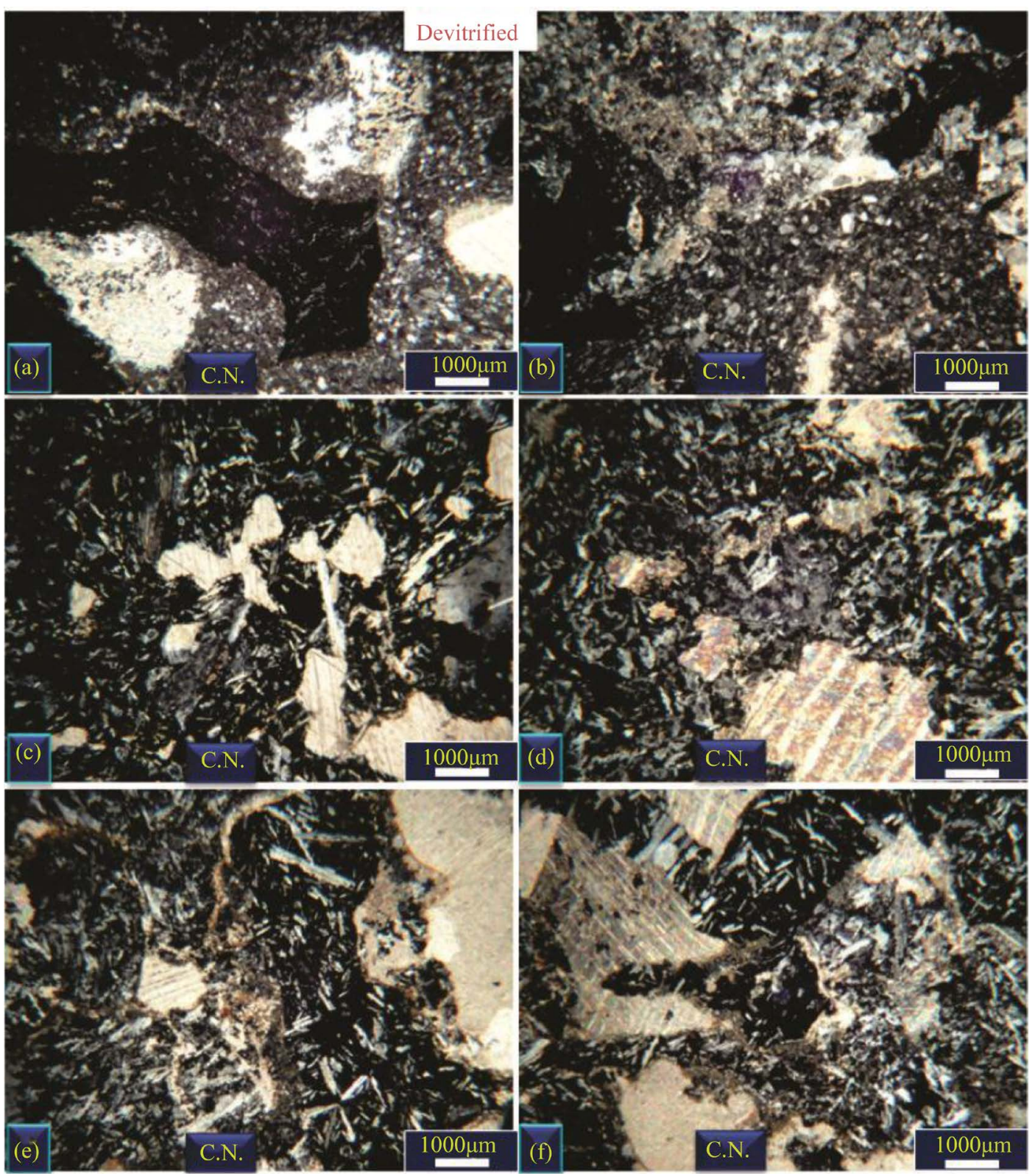

Figure 13. (a) (b) Fine-grained devitrified basalt in the lower part of unit III and it is composed from Ca-plagioclase crystallites (light grey) embedded within very fine glassy matrix (black); (c) (d) In the devitrified basalt, the glassy matrix becomes slightly crystalline giving rise to light grey groundmass of Ca-plagioclase crystallites and microcrystalline quartz; (e) (f) The devitrified basalt becomes holocrystalline and constituents of this basalt becomes slightly calcitized and large blocky calcite crystals are seen formed instead of the basaltic components (light).

Microscopically, this basalt type is composed from Ca-plagioclase with very minor "rare" mafic pyroxene lathes. It suffers from progressive and subsequent stages of calcitization of the Ca-plagioclase lathes, the enclosing fine glassy matrix and finally the very rare pyroxene crystals (Figures 14(c)-(f)). The stages of calcitization begin by the formation of very small calcite domains in between the different constituents of basalt (Figure 14(c)). During more advanced stages, the calcite domains become larger and the calcite crystals becomes of rhombohedral cleavage (Figure 14(d) and Figure 14(e)). Ultimate stages of calcitization led to the formation of wide white areas of blocky calcite that contains very small relicts of the original basaltic composition "mottling", i.e. pseudo-breccia (Figure 14(f)). 

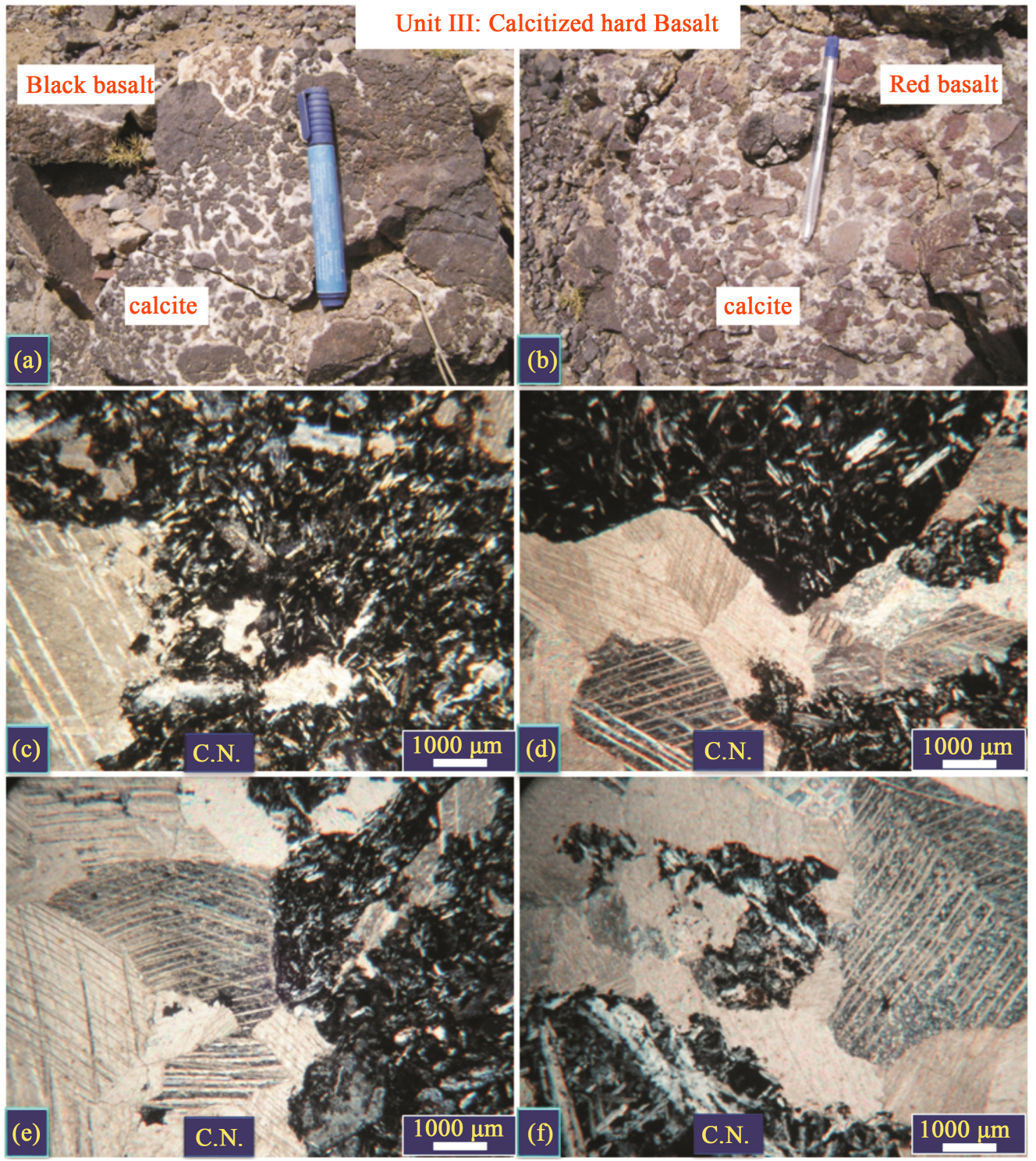

Figure 14. (a) (b) Hard calcitized basalt on the topmost part of unit III, it is poorly bedded and it is composed from mottled "in situ pseudo-brecciated" basalt of black basaltic domains and light calcite domains; (c)-(f) Progressive and subsequent stages of calcitization and replacement of the different basaltic components "grey and black" by the light rhombohedral calcite crystals.

\section{Discussion and Conclusions}

The present study submits very detailed stratigraphic and petrographic description of the upper part of Girshah Formation in Wadi Al Roian area. This part is just underlying the contact between Girshah Formation (the aim of the present study) and the overlying acidic volcanics and the associated volcaniclastics (dolostones, sandstones, conglomerates, rhyolites and rhyolitic tuffs) of Ablah Formation. The result of the detailed and careful field works and microscopic description of the studied succession of the volcaniclastic red beds and the associated scoriaceous basalts of the upper part of Girshah Formation revealed that: 1) The studied succession represents a good vertical gradation from basic and intermediate system that predominated during the Girshah Formation (most probably at the final stage of alluvial fan on mature arc) into continental sedimentation predominated by acidic volcanic eruption; 2) The lower unit is composed mainly from green epidotized and silicified basaltic and andesitic tuffs which indicate the deposition of the tuffaceous materials in high water column far away from the areas of volcanic eruptions; and 3) After the filling of this water column, the condition becomes 
suitable for the deposition of the tuffaceous material in normal sedimentary lacustrine environments suitable for the formation of the volcaniclastic red beds and the overlying scoriaceous basalts.

The three main units of the studied succession are summarized here as follows:

1) The lower epidotized and silicified basaltic andesitic tuff unit which represents deposition of basic to intermediate tuffs within slightly saline depositional environments. This is indicated by the formation of green iron silicate ferrous iron-rich minerals, i.e. celadonites and epidote. Similar situation of formation of ferrous green iron silicate minerals has been described by [5] and [6]. They postulated the formation of green glauconitic clay by synsedimentary authigenic processes as a result of the reaction between $\mathrm{K}^{1+}$, $\mathrm{Fe}^{2+}$, and $\mathrm{Mg}^{2+}$ in slightly reducing conditions.

2) The middle volcaniclastic red beds-scoriaceous basalt unit of successive cycles. Each of these cycles begins by reddish tuffaceous mudstone and sandstone and is terminated by the calcite-bearing scoriaceous basalt. This unit indicated deposition in lacustrine condition and the red color was formed either by the direct hematitization of the deposited tuffs or by the diagenetic hematitization of the green clays formed instead of the precursor tuffaceous materials. Similar volcaniclastic red beds in Tayebit El Esm area have been related by [4] to the following stages: 1) the deposition of the basic and intermediate volcanic ashes in slightly deeper environments, 2) the degradation of the deposited volcanic ash and the diagenetic authigenesis of green celadonitic clays either along the sediment/water interface or beneath the sea floor by the interaction between $\mathrm{Fe}^{2+}, \mathrm{Mg}^{2+}, \mathrm{Si}^{4+}$ and $\mathrm{Al}^{3+}$, 3) the diagenetic hematitization of the formed green celadonitic clays of stage 1 and the formation of the iron-oxyhydroxides mineral i.e. goethite and hematite as a result of the change in the pore water sediments from reducing to oxidizing conditions, and 4) finally, the direct hematitization of the originnal tuffaceous materials and formation of iron minerals especially in the upper parts of the volcaniclastic red beds succession (oxidized areas within the depositional environments).

3) The upper scoriaceous basalt unit that composed from hematitized and calcitized basalt. This unit was formed by basic volcanic eruption in subaerial condition which predominated by the formation of calcium carbonate lakes associated with the progressive and subsequent calcitization of the Ca-plagioclase minerals of the basalt and the associated glassy tuffaceous material. The rift-related Oligo-Miocene basalts and the associated scoria deposits of the western part of Saudi Arabai "Harrat" has been previously studied by many authors [7]-[14]. The scoria reserves in Saudi Arabia are extensive. No serious assessments were made as to the quantity or the quality of these deposits. The estimated reserves in the four locations investigated within central Harrat Rahat namely Jabal Halat Ash Shaykh, Jabal Al Hala, Jabal Suwah and Jabal As Sahiliyah amount to 5 million $\mathrm{m}^{3}$ [15]. In wadi Al Roaian area (the study area), the scoria deposits are only represented by scoriaceous basalts that is massive and highly calcareaous and no true scoria deposits are observed. Further geologic investigations are required to search about the scoria deposits that may present as lateral equivalent facies for the present scoriaceous basalts of the study area. The studied succession represents the distal part of the coarse volcaniclastic basaltic and andesitic agglomerates of Girshah Formation. It represents deposition in high water column which resulted in the entire dissolution and degradation of the precursor tuffaceous materials and formation of the volcaniclastic red beds. The scoriaceous basalts of the uppermost part of the succession were formed as a result of the intensive and subsequent steps of calcitization and oxidation of the different constituents of the eruptive basaltic materials.

\section{Acknowledgements}

The author submits deep thanks for the Faculty of Earth Sciences "FES”, King Abdulaziz University "KAU” for the field facilities. Also many thanks to the editors of the OJG for the revision and editing of the manuscript.

\section{References}

[1] Zakir, F. (1972) Geology of the Ablah Area, Southern Hijaz Quadrangle, Kingdom of Saudi Arabia. M.Sc Thesis, South Dakota School of Mines and Technology, Rapid City, South Dakota, 66 p.

[2] Johnson, P.R. (2006) Explanatory Notes to the Map of Proterozoic Geology of Western Saudi Arabia. Technical Report SGS-Tr-2006-4.

[3] Taj, R.J., Mesaed, A.A., Moufti, A., Qari, M.A.T. and Matsah, M.I. (2010) Origin and Diagenetic History of the Fluvio-Lacustrine/Deltaic Volcaniclastic Red Beds, W. Girshah-W. Halwate, Ablah District, Western Arabian Shield, Saudi Arabia. Fifth International Conference on the Geology of the Tethys Realm, South Valley University, 5-7 Janu- 
ary 2010, 227-248.

[4] Moufti, M.A. and Mesaed, A.A. (2015) Origin and Geochemistry of the Late Proterozoic Intra-Arc Rift-Related Volcaniclastic Red and Green Beds of Tayibit El Esm Area, Ablah District, South Central Arabian Shield, Saudi Arabia. Arabian Journal of Geosciences, 8, 7515-7536. http://dx.doi.org/10.1007/s12517-014-1675-5

[5] Mesaed, A.A. (1999a) Stratigraphic Setting and Paleoenvironments of the Bartonian-Priabonian Glaucony Facies of the Northern Part of the Western Desert, Egypt. Egyptian Journal of Geology, 43/2, 1-27.

[6] Mesaed, A.A. and Surour, A.A. (2000) Mineral Chemistry and Mechanism of Formation of the Bartonian Glaucony of El Gedida Mine, El Bahariya Oases, Egypt. Egyptian Mineralogist, 12, 1-28.

[7] Brown, G.F., Jackson, R.O., Bogue, R.G. and Elberg Jr., E.L. (1963a) Geologic Map of the Northwestern Hijaz Quadrangle, Kingdom of Saudi Arabia. U.S. Geological Survey Miscellaneous Geologic Investigation Map I-204A, Scale 1:500,000.

[8] Brown, G.F., Jackson, R.O., Bogue, R.G. and Maclean, W.H. (1963b) Geologic Map of the southern Hijaz Quadrangle, Kingdom of Saudi Arabia. U.S. Geological Survey Miscellaneous Geologic Investigation Map I-210A, Scale 1:500,000.

[9] Brown, G.F. (1972) Tectonic Map of the Arabian Peninsula. Saudi Arabian Directory General for Mineral Resources, Arabian Peninsula Map, AP-2 (1:4,000,000).

[10] Camp, V.E. and Roobol, M.J. (1987) Geologic Map of the Cenozoic Lava Field of Harrat Rahat, Kingdom of Saudi Arabia. Saudi Arabian Deputy Ministry for Mineral Resources Open File Report DGMR-OF-07-9, 91 p.

[11] Camp, V.E. and Roobol, M.J. (1989) The Arabian Continental Alkali Basalt Province: Part II. Evolution of the Harrat Rahat, Kingdom of Saudi Arabia. Geological Society of America Bulletin, 101, 71-95. http://dx.doi.org/10.1130/0016-7606(1989)101<0071:TACABP>2.3.CO;2

[12] Roobol, M.J., Simsim, M., Tayeb, O. and Abdul-Hafaz, K. (1998a) Basalt as an Industrial Rock-1. Al Madinah Area: Quarry Sites for Al Madinah Al Munawwarah. Saudi Arabian Deputy Ministry for Mineral Resources Technical Report BRGM-TR-98-1, $84 \mathrm{p}$.

[13] Roobol, M.J., Abdul-Hafaz, K., Simsim, M. and Tayeb, O. (1998b) Basalt as an Industrial Rock-2. Central Harrat Rahat: Quarry Sites for Jeddah and Makkah al Mukarramah. Saudi Arabian Deputy Ministry for Mineral Resources Technical Report BRGM-TR-98-7, 50 p.

[14] Roobol, M.J., Simsim, M., Abdul-Hafaz, K. and Tayeb, O. (1999) Basalt as an Industrial Rock-3. Harrat Kishb: Quarry sites for At T'if, Ar Riyadh and Ad Dammam. Saudi Arabian Deputy Ministry for Mineral Resources Technical Report BRGM-TR-98-13, $117 \mathrm{p}$.

[15] Moufti, M.R., Sabtan, A.A, El-Mahdy, O. and Shehata W.M. (1998) Geologic and Engineering Assessment of the Pyroclastic Deposits in the Central Part of Harrat Rahat. Final Report of Project 417/201 Submitted to KAU. 5th Meeting of Saudi Society Earth Sciences, Dhahran, 26-29 October 1998, Abstract, 25.

\section{Submit or recommend next manuscript to SCIRP and we will provide best service for you:}

Accepting pre-submission inquiries through Email, Facebook, Linkedin, Twitter, etc

A wide selection of journals (inclusive of 9 subjects, more than 200 journals)

Providing a 24-hour high-quality service

User-friendly online submission system

Fair and swift peer-review system

Efficient typesetting and proofreading procedure

Display of the result of downloads and visits, as well as the number of cited articles

Maximum dissemination of your research work

Submit your manuscript at: http://papersubmission.scirp.org/ 